\title{
SCHOOL ADAPTATION MONITORING AS A TOOL OF THE PSYCHOLOGICAL SUPPORT SYSTEM IN THE EDUCATIONAL PROCESS
}

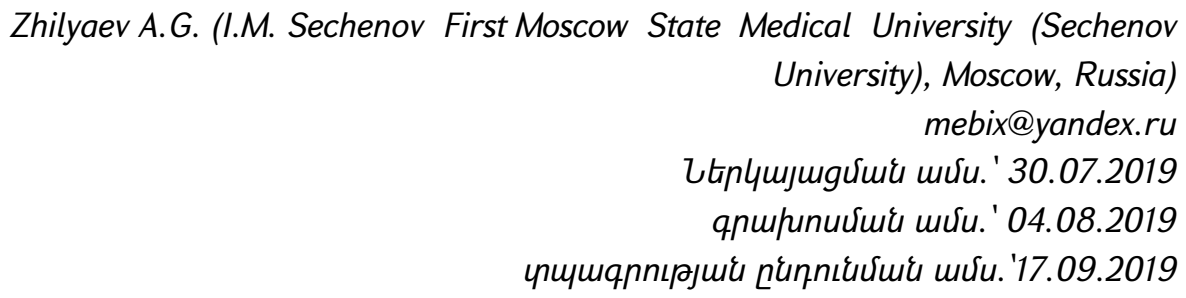

Psychological adaptation of children to the learning environment is one of the key characteristics providing an effective "health map" in learners (pupils), as far as this particular feature represents the foundation of successful personal development and education of a child (learner, pupil). Psychological maladjustment is an early and objective predictor of the risk of maladaptive changes in the psychophysiological state of learners. The state of psychological maladaptation is characteristic of an early stage of behavioral disorders in children. Psychological disadaptation may be directly associated with impaired health, both psychological and physical, or learning disability, or may combine all the above aspects. Monitoring represents a simple, available and effective tool for objective dynamic surveillance on the psychological status, it enables identifying negative trends in the mental state of children (learners) in course of the learning process.

Keywords: monitoring, psychological adaptation, screening, fatigue, psychophysiology, health map, psychology in education.

Psychological adaptation is one of the key phenomena in the psychophysiological health of a child reflecting his or her psychological and personality characteristics within the framework of the learning process [5].

Psychological screenings make it possible to measure the psychological characteristics of fatigue that represent major criteria of a child's level of adaptation to the educational institution environment. The system of psychological support for the learning process involves the dynamic diagnostics of psychophysical fatigue in learners. The system enables identification of psychological maladjustment risk groups and differentiation of psychological characteristics of the children. Evidence-based dynamic observation of learners' psychological status is carried out through analyzing the data obtained by school adaptation monitoring. This provides dynamic forecasting of trends in child's personal development. The school adaptation monitoring data empowers us to significantly expand the base of the predictors of maladaptive tendencies (both in individual pupils (learners) and in classes (groups)) for the objective ultra-early detection of psychological maladaptation. Monitoring school adaptation enables us to effectively elaborate personality-oriented measures for individualized psychoprophylaxis and therapy for the 
factors negatively affecting the psychological adaptation of learners (pupils) $[8,9,10]$. The interconnection of the school adaptation monitoring system and the psychological programs "Parent school" and "Teacher's health" is an essential component of the system of psychological support for learners within educational institutions.

Developing the project "The School Adaptation Centre" (which involves school adaptation monitoring), the programs "Parent school" and "Teacher's health" can significantly improve the efficiency of the interaction between the main subjects of the educational process, which helps to create optimum conditions for developing the personality of a learner (pupil) [2].

The principal aims and objectives of the project "The School Adaptation Centre" are:

- Providing psychological and educational support to learners and their families as well as teachers in the context of the learning process.

- Carrying out assessments and dynamic observations of the level of adaptation of learners in course of the learning process.

- Maintaining control over recreational activities for physically challenged learners having chronic diseases and experiencing difficulties in psychological adaptation.

- Prevention of deviant behavior in learners: violence, aggression, self-aggression (risk of suicidality), behavioral response, drug and alcohol involvement, smoking [6, 7].

- Developing skills of psychologically effective cooperation.

- Prevention and psychological correction of stress-related disorders both in learners and in teachers.

The main activities of the project "The School Adaptation Centre" are:

1) "School Adaptation Monitoring" - psychological screening.

2) "Parent school" - family counseling, training workshops.

3) "Teacher's health" - counseling, resilience trainings.

The methodological basis of family counseling within the framework of the program "Parent School" involves providing assistance to learners (pupils) and their families in psychologically challenging cases, including development problems and health limitations.

Family counseling goals:

1) Assessment of psychological, psychomotor and psychoverbal development of learners (pupils).

2)Assistance in cases of learning and school adaptation problems.

3) Family interaction improvement.

4)Prevention of stress-related disorders, addictive behavior, aggression and selfaggression, deviant behavior.

Consultants: a psychologist, an educator, a speech therapist, a rehabilitation therapist.

In consequence of providing family counseling, we arrive at the dynamic control over the level of learners' psychophysical adaptation, individual recreation programmes 
and the corrective activities efficiency control. The structure of the essential educational programmes of the "School Adaptation Centre" is as follows:

I. The training course "Development of Positive Communication Skills"- its purpose is to develop communication skills and prevent deviant behavior:

1. For students of primary grades (an interactive training).

2. For teenagers (an interactive training).

3. For high school students (an interactive training).

4. For parents (a training workshop).

5. For teaching staff (a training workshop).

II. The training workshop "Prevention of Addictive Behavior" is aimed at forming drug- and alcohol-avoidance attitudes, prevention of smoking and computer addiction [3].

1. For grades 1-4 (a metaphorical training - fairytale therapy) [1, 4].

2. For grades 5-11 (an interactive training).

3. For teachers and parents of students (a training seminar).

III. The training seminar "Raising stress tolerance" is aimed at developing stress resistance skills for handling stressful situations like exams and conflicts:

1. For younger schoolchildren (a play training).

2. For grades 5-11 (a training; psychological self-regulation).

3. For teachers (teaching techniques for preventing professional burnout).

Inclusion of the school adaptation monitoring results into the health map structure of a learner makes possible:

Systematic dynamic observation and objective control over the trends of the psychological states of learners (pupils).

Ultra-early detection of psychological maladaptation risk groups and differentiated assessment of the following factors: psychophysical development and psychological health, learning difficulties, the risk of formation of deviant behaviors.

Evidence-based control over the efficiency of the corrective, developmental and recreational activities of the educational process.

Improving parent-child relations and conditions of intra-family communication. Enhancing psychological adaptation of teachers, raising professional stress tolerance, preventing emotional burnout and stress-related health disorders in teachers.

\section{References}

1. Khoukhlaeva O.V., Khoukhlaev O.E Therapeutic fairy tales for correction work with children // Moscow: Forum Press. 2013. p. 152.

2. Kouchma V.R., Zvezdina I.V., Zhigareva N.S. Medico-social aspects of health formation in younger schoolchildren// Issues of modern pediatrics. v.7. №4. 2008. pp. 9-12.

3. Palachyova T.I. Personality traits of schoolchildren - older adolescents, with different attitudes towards alcohol // Moscow: Psychology PhD thesis. 2016. p. 182). 
4. Shal L.G., Maksimenko M.Y., Zhilyaev A.G. Age characteristics of visualfigurative thinking of schoolchildren, both in normal and in autism spectrum disorders // Proceedings of P.F.Lesgaft University. №7 (125). 2015. pp. 227-233.

5. Vygotsky L.S. Educational psychology// introduced by V.V.Davydov - Moscow: Pedagogy Press. 1996. p.536).

6. Zhilyaev A.G., Palachyova T.I. A comprehensive personality-oriented programme for forming a healthy lifestyle and the primary prevention of drug addiction in schoolchildren. A methodology guide // Kazan: Kazan State Technological University Press. 2010, p.495.

7. Zhilyaev A.G., Palachyova T.I. A metaphorical training for creating a negative image of drug addiction in childhood // Kazan: Offset-service. 2017. p.188.

8. Zhilyaev A.G. Intensive methods of assessing psychological status, identifying and correcting psychological maladjustment// Kazan: 2004, p.91.

9. Zhilyaev A.G. Health monitoring. Learning without getting ill // Teacher's Newspaper of Moscow. - Moscow: 2017. № 14.

10.Zhilyaev A.G., Palachyova T.I. Methods of diagnosis and correction of psychological maladjustment. // A monograph - Kazan: 2015. p.174.

\section{«МОНИТОРИНГ ШКОЛЬНОЙ АДАПТАЦИИ КАК ИНСТРУМЕНТ СИСТЕМЫ ПСИХОЛОГИЧЕСКОГО СОПРОВОЖДЕНИЯ ОБРАЗОВАТЕЛЬНОГО ПРОЦЕССА»}

Жиляев А.Г. (Первый Московский государственный медицинский университет им. И.М. Сеченова, Москва, Россия

Психологическая адаптация ребенка к условиям образовательного процесса одна из основных характеристик эффективного "паспорта здоровья" обучающихся (воспитанников), так как именно она является основой успешного развития личности и обучения ребёнка (воспитанника, обучающегося). Ранним и объективным предиктором риска развития дезадаптивных изменений психофизиологического состояния обучающихся является снижение уровня психологической адаптации. Психологическая дезадаптация может быть непосредственно связана с нарушениями здоровья как психологического, так и физического, или трудностями обучения, или сочетать в себе все вышеперечисленные аспекты. Мониторинг отличается доступностью и простотой, представляет собой эфффективный инструмент динамического объективного контроля психологического состояния, позволяющий выявить негативные тенденции в психологическом состоянии детей (обучающихся) в рамках образовательного процесса.

Ключевые слова: мониторинг, психологическая адаптация, скрининг, утомляемость, психофизиология, паспорт здоровья, психология в образовании. 